in relation to the nearest river makes it possible to identify many locations accurately.

\section{SUM M ARY}

Timothy Flint's accounts of the Middle West from 1816 to 1845 are among the most extensive and accurate for ecological use of the accounts listed in the Literature of the Middle Western Frontier (Rusk 1925). Flint includes numerous accounts of prairies, including a type he refers to as "bushy," or "hazel," prairies; descriptions of forest types, of soils, and of species ranges. Consequently his work is a reliable source of description of the original vegetation of the Ohio and Mississippi valleys.

\section{REFERENCES}

Flint, Timothy. 1826. Recollections of the Last Ten Years, Boston. Also available in an edition by Alfred Knopf, New York, 1932.

- 1828. A Condensed Geography and History of the Western States, Cincinnati.
1832 The History and Geography of the Mississippi Valley, 2nd ed., Cincinnati.

- 1835. "Sketches of Travel, number two" Knickerbocker Magazine, V, 230 (April).

Hall, James. 1829. "Review of a Condensed Geography and History of the Western States," American Quarterly Review, V, 343 (June).

Kirkpatrick, John Ervin. 1911. Timothy Flint, Cleveland.

Paulding, James K. 1849. "The Illinois and the Prairies" Graham's American Monthly Magazine, XXXIV, 16 (Jan.).

Rusk, Ralph L. 1925. The Literature of the Middle Western Frontier, Cambridge University Press, 1925.

Philip Whitford

AND

KATHRYN WHITFORD

Botany Department and English Department

University OF Wisconsin-Milwaukee

\title{
STANDING CROP OF HERBACEOUS VEGETATION IN SOUTHERN MICHIGAN
}

Few papers have been published giving data on the productivity or standing crop of herbaceous vegetation in the United States (Bray et al. 1959). During a study of the local distribution of small mammals in southern Michigan, data were obtained on the standing crop of herbaceous vegetation, primarily to determine the cover and food available in various habitats. Part of these data have been presented in connection with the mammal study (Getz 1959). Since such information is relatively rare in the literature, it seems advisable to make it available in greater detail.

I wish to thank Dr. W. S. Benninghoff for suggestions during the study and in the preparation of the manuscript. Dr. F. C. Evans also offered suggestions concerning the manuscript.

\section{Description of the Study Area}

The standing crop was determined for several components of the herbaceous vegetation in 4 different habitats: a marsh, an abandoned field, a bog mat, and an upland hardwood forest stand. All were located in the University of Michigan's Mud Lake Research Area, Washtenaw County, Michigan.

Marsh.-The site of this stand is for the most part typical of marsh habitats. The surface is topographically low and poorly drained with the water table only a few centimeters below the surface. During the wet season (October through April) most of the area (included in the study) is inundated. The soil is typical of marshes (Dansereau 1957); it contains much fibrous, peaty humus and a moderate amount of mineral matter. The soil water content is high even when not inundated; it is nearly saturated during the driest months. The predominant sedges and grasses form small tussocks $5-10 \mathrm{~cm}$ in diameter. Each tussock is $5-10 \mathrm{~cm}$ tall.

Old field.-This is an abandoned field that has not been under cultivation for approximately 15 years. The last crop it produced was maize. There is a small depression with a drainage outlet in the northern part of the field. The outlet is bordered by a dense stand of sedges which was not sampled, as such vegetation is not typical of abandoned fields. The southern portion of the field slopes down to a point approximately $3 \mathrm{~m}$ below the field level. The soil is a sandy loam (Miami loam) except in the low, moist sites which have a slightly higher humus content. Sheet erosion on the slopes has removed most of the top soil, exposing sandy clay. The soil becomes very dry during the summer.

Bog mat.-The bog area is adjacent to the north margin of Mud Lake. It is a typical Sphagnum bog mat, soft and springy but able to support a man's weight. Several different plant communities occur, but the study was limited to an area in which the dominant plants (in addition to Sphagnum) were a sedge, Carex lasiocarpa, and a fern, Dryopteris Thelypteris. The water level is usually $10-15 \mathrm{~cm}$ below the surface except for small depressions in the mat where standing water is exposed. The subsurface material is, therefore, very wet at all times; it is composed almost entirely of decaying vegetation and is covered by Sphagnum.

Upland hardwoods.-This area is situated on an "island" lying in a low marsh. Its highest points are 4-5 $\mathrm{m}$ above the surrounding marsh. It is characterized by a mature oak-hickory stand with sedges and forbs predominant in the field stratum. The tree canopy is closed. Leaf litter and humus layers of the soil are well developed and there are numerous fallen trees in the area. The study is on a site where the field stratum is composed primarily of Carex rosea. Phytosociological lists of predominant plants of all 4 areas are given by Getz ( $o p$. cit.).

\section{METhods}

Quadrats were located in each area so that representative samples of all variations of the vegetation in the study area would be obtained. When the approximate position for a quadrat was determined, a pair of clippers was thrown into the site. From the point where the clippers landed, the quadrat was aligned with sides parallel to the previously positioned quadrats. A square wooden frame with inside dimensions of one meter on each side was used to delimit the quadrat. Vegetation within the frame, regardless of where it was rooted, was clipped approximately $5 \mathrm{~cm}$ above the surface. Samples thus obtained were bagged, air dried, and separated for 
weighing. Samples from all areas were processed at the same time.

Two series of samples were taken, one in March, 1958, the other in June (old field) and July, 1958 (marsh, bog mat, and upland hardwoods). All the summer plots were located adjacent to the March plots. Samples taken during the summer represent the peak growth for each area. Because of numerous standing dead stems of grass in the old field in June, it was not feasible to separate all living stems. To determine the standing crop for this area, the amount in the March samples was subtracted from the amount in the June clippings. These data were further checked by clipping 6 of the plots that were clipped in March. Although some vegetation may have decayed between March and June, comparisons with the yield from the plots clipped in March indicated it was not significant enough to bias the data.

The following number of plots were clipped in each series : marsh, 36 ; old field, 26 ; bog mat, 5 ; upland hardwoods, 5.

Water depths in the marsh were recorded at each plot in April, 1958. A greater portion of the marsh was inundated at this time than during any other month. The data obtained have been used to correlate the moisture present with the standing crop of vegetation. Although no standing water was present after July, 1958, the plots that had greater depths of standing water in April contained standing water later into the summer. Available moisture was, therefore, greater at these sites than at those on which the water depths were less in April.

\section{RESULTS}

The predominant species of sedges and rushes in the marsh were treated individually, and the standing crop of each was determined. The remainder of the sedges, the grasses (Glyceria striata, Phalaris arundinacea, Calamagrostis canadensis) and the forbs (primarily Eupatorium purpurea, Impatiens capensis, Aster simplex, and Galium sp.) were not separated according to species. The standing crop of each of the more abundant species in the old field (Poa compressa, Potentilla intermedia, and Daucus carota) was determined separately.

The standing crop for the marsh was $465 \pm 121 \mathrm{gr} / \mathrm{m}^{2}$ (Table I) as compared to $170 \pm 36 \mathrm{gr} / \mathrm{m}^{2}$ for the old field (Table II). This difference is significant at the .01 level $(t=3.88)$. The standing crop of forbs in the marsh was $75 \pm 66 \mathrm{gr} / \mathrm{m}^{2}$ as compared to $105 \pm 30 \mathrm{gr} / \mathrm{m}^{2}$ in the old field. This difference was not significant $(t=0.86)$. The standing crop of grasses in the marsh was $70 \pm 93 \mathrm{gr} / \mathrm{m}^{2}$ while that for the old field was $65 \pm 58 \mathrm{gr} / \mathrm{m}^{2}$. The difference was not significant $(t=0.24)$. The greater total standing crop of the marsh results from the several common species of sedges.

The standing crops for the bog mat and upland hardwoods are as follows:

\begin{tabular}{lrr}
\multicolumn{4}{c}{ Bog mat } \\
$\begin{array}{l}\text { Dryopteris Thelypteris } \\
\text { Carex lasiocarpa }\end{array}$ & $115 \pm 65 \mathrm{gr} / \mathrm{m}^{2}$ & $(40-175)$ \\
& $45 \pm 22 \mathrm{gr} / \mathrm{m}^{2}$ & $(20-60)$ \\
Uarex rosea & Upland hardwoods \\
Forbs & $45 \pm 8 \mathrm{gr} / \mathrm{m}^{2}$ & $(30-50)$ \\
F & $5 \pm 3 \mathrm{gr} / \mathrm{m}^{2}$ & $(5-10)$
\end{tabular}

The standing crop of sedges was, therefore, approximately the same on the bog mat and in the upland hardwoods. The standing crop of sedges in these two areas was significantly different (at the .01 level) from the total standing crop of sedges in the marsh $(t=2.84$ and 2.73 for the upland hardwoods and bog mat respectively). The standing crop of Dryopteris Thelypteris in the marsh
TABLE I. Standing crop of herbaceous vegetation and correlations with available moisture in a grass-sedge marsh.

\begin{tabular}{|c|c|c|c|c|c|c|}
\hline \multirow[b]{2}{*}{ Plant } & \multirow{2}{*}{$\begin{array}{l}\text { No. of plots } \\
\text { in which it } \\
\text { occurred }\end{array}$} & \multicolumn{3}{|c|}{ Standina Crop $\left(\mathbf{G R} / \mathbf{M}^{2}\right)$} & \multirow{2}{*}{$\begin{array}{l}\text { Correla- } \\
\text { tion with } \\
\text { moisture* }\end{array}$} & \multirow[b]{2}{*}{$\begin{array}{l}\text { Proba- } \\
\text { bility** }\end{array}$} \\
\hline & & Mean & Range & $\begin{array}{l}\text { Stand. } \\
\text { Dev. }\end{array}$ & & \\
\hline Carex lacustris. & 27 & 165 & $0-730$ & 170 & +.44 & $<.01$ \\
\hline $\begin{array}{r}\text { Carex sp. (ovales } \\
\text { section) } . . .\end{array}$ & 6 & 40 & $0-310$ & 89 & & \\
\hline $\begin{array}{l}\text { Misc, sedges....... } \\
\text { Sparganium }\end{array}$ & 5 & 20 & $0-240$ & 48 & $\ldots$ & $\ldots \ldots$ \\
\hline eurgearpum..... & 11 & 45 & $0-430$ & 104 & +.44 & $<.01$ \\
\hline Scirpus americana. . & 4 & 10 & $0-200$ & 40 & $\ldots$ & $\ldots$ \\
\hline Grasses . . . . . . . . & 24 & 70 & $0-440$ & 93 & -.20 & $\ldots$ \\
\hline Forbs........ & 36 & 75 & $5-310$ & 66 & -.53 & $<.01$ \\
\hline Dryopteris & & & & & & \\
\hline Thelypteris...... & 22 & 30 & $0-105$ & 38 & -.50 & $<.01$ \\
\hline Typha latifolia. .... & 8 & 10 & $0-220$ & 32 & $\ldots$ & $\cdots \cdots$ \\
\hline Total. & 36 & 465 & $265-650$ & 121 & & $\ldots \ldots$ \\
\hline
\end{tabular}

* Spearman Rank Correlation Coefficient.

** Level of significance.

TABLE II. Standing crop of herbaceous vegetation in an abandoned field.

\begin{tabular}{|c|c|c|c|}
\hline \multirow{2}{*}{ Species } & \multicolumn{3}{|c|}{ Standing Crop (GR/M $\left.\mathbf{M}^{2}\right)$} \\
\hline & Mean & Range & $\begin{array}{l}\text { Standard } \\
\text { Deviation }\end{array}$ \\
\hline $\begin{array}{l}\text { Poa compressa ...... } \\
\text { Pcientilla intermedia. } \\
\text { Daucus Carota...... } \\
\text { Other forbs........ }\end{array}$ & $\begin{array}{l}65 \\
70 \\
25 \\
10\end{array}$ & $\begin{array}{l}5-240 \\
0-160 \\
0-90 \\
0-90\end{array}$ & $\begin{array}{l}58 \\
49 \\
27 \\
17\end{array}$ \\
\hline Total. . & 170 & $110-260$ & 36 \\
\hline
\end{tabular}

was significantly less (at the .01 level) than that on the bog mat $(t .=4.72)$.

Correlations of standing crop with available moisture are shown in column 5 of Table I. Correlations were determined by the Spearman Rank Correlation coefficient (Siegel 1956). There is a positive correlation between available moisture and the standing crop of Carex lacustris and Sparganium eurycarpum (significant at the .01 level) and a negative correlation (also significant at the .01 level) between the available moisture and the standing crop of forbs and Dryopteris Thelypteris. A slight, but not significant, negative correlation also existed between the standing crop of grasses and the amount of moisture present. Soil moisture data were obtained for the old field, but differences were not considered significant enough to attempt correlations with the standing crop.

\section{SUM MARY}

The standing crop of herbaceous vegetation was determined for four habitats in southern Michigan : a marsh, an abandoned field, a bog mat, and an upland hardwood forest.

The total standing of crop of the marsh was significantly greater than that of the abandoned field (465 and $\left.170 \mathrm{gr} / \mathrm{m}^{2}\right)$. The standing crop of sedges in the marsh was significantly greater than on the bog mat or in the upland hardwoods $\left(225,45\right.$, and $45 \mathrm{gr} / \mathrm{m}^{2}$ respectively). The standing crop of Dryopteris thelypteris was 
significantly greater on the bog mat than in the marsh ( 115 and $30 \mathrm{gr} / \mathrm{m}^{2}$ respectively).

In the marsh there was a positive correlation of the standing crop of sedges and rushes with available moisture. There was a negative correlation with the standing crop of ferns and forbs with available moisture.

\section{REFERENCES}

Bray, J. R., D. B. Lawrence, and L .C. Pearson. 1959. Primary production in some Minnesota terrestrial communities for 1957. Oikos 10: 38-49.

Dansereau, P. 1957. Biogeography. An ecological perspective. New York. Ronald Press : 394 pp.
Getz, L. L. 1959. An analysis of some of the factors influencing the local distribution of small mammals in southern Michigan. Unpubl. Thesis, Univ. Michigan.

Siegel, S. 1956. Nonparametric statistics for the behavioral sciences. New York, McGraw-Hill Co. : 312 pp.

LOWELL L. Getz

\author{
MUSEUM OF ZOOLOGY \\ UNIVERSITY OF MICHIGAN \\ AnN Arbor, Michigan
}

\section{EXPERIMENTAL GERMINATION OF SEED AND ESTABLISHMENT OF SEEDLINGS OF PHRAGMITES COMMUNIS}

Examination of the vegetation which volunteered on mud flats at the Mud Lake National Wildlife Refuge in Northwestern Minnesota during the summer of 1953 revealed seedlings of a grass which the senior author tentatively identified as Phragmites communis Trin. Identification was made on the basis of the seed coat adhering to the roots of the youngest seedlings. During subsequent conversations, the late Dr. Norman C. Fassett indicated that definite germination of this species had not been reported. This led the authors to attempt to germinate Phragmites seed in the laboratory and to label a number of the seedlings on the mud flats so they could be relocated and identified after they had matured.

Seeds used in the germination experiments were contained in seed heads collected from a group of Phragmites plants growing on one of the refuge dikes in September, 1953. Germination tests were conducted in the laboratory in St. Paul by selecting well-filled florets from the heads and placing them in petri dishes of tap water. Laboratory tests were made on samples of seed after 3-6 months storage. The 6 month's tests included seed which had been stored dry in paper bags at room temperature, seed stored wet in glass vials at room temperature, seed stored dry in glass vials at outside temperatures (alternate freezing and thawing during the winter) and seed stored wet in glass vials at outside temperature. No germination was obtained in any of these tests.

Additional tests were conducted after 7 months storage.

${ }^{1}$ Paper No. 4227, Scientific Journal Series, Minnesota Agricultural Experiment Station, St. Paul 1, Minnesota.
Seeds were placed in corked glass vials that had been halffilled with water. These were set out of doors in a wooden rack at St. Paul, Minnesota, and exposed to normal variations of outside temperature and light in late April. Four such tests, which were conducted on seeds that had been stored wet at outside temperature, gave no germination. However, in 4 tests made on seed stored at room temperature for 7 months, seeds in 19 of 40 florets germinated, or an overall percentage of nearly 50 per cent. One further test was made on seed stored dry at room temperature after 8 months and 30 per cent of the seeds in 150 germinated.

Examination of the staked seedlings on the mud flats in late summer of 1954 revealed without any possible doubt that the plants in question definitely were Phragmites communis Trin.

While these germination tests were not of an extensive or large scale nature, they do show that Phragmites communis Trin. seeds can be germinated experimentally and document the establishment of seedlings in nature.

\section{STANLEY W. HarRis}

AND

William H. Marshall

Division of Natural Resources

Humboldt State College

Arcata, California

AND

Department of Entomology and Economic Zoology

University of Minnesota

St. Paul, Minnesota

\section{AN ORGANIZATIONAL HIERARCHY POSTULATE FOR THE INTERPRETATION OF SPECIES-INDIVIDUAL DISTRIBUTIONS, SPECIES ENTROPY, ECOSYSTEM EVOLUTION, AND THE MEANING OF A SPECIES-VARIETY INDEX}

\section{Species-Individual Distributions}

One of the most fascinating and heretofore unexplained properties of ecological systems is the widespread similarity in the numerical distribution patterns of individuals and species in communities. Not only are there a few species present with many individuals and many species present with a few individuals of each, but the common and rare are related in ways suggesting logarithmic functions. Some principal graphs used are the following:
Number of species vs. number of individuals per species.-Willis (1922) plotted species versus individuals per species, obtaining curves in a wide variety of communities which resembled hyperbolas superficially, but were shown by Fisher, Corbet, and Williams (1943) to more closely resemble logarithmic series.

Cumulative species ws. logarithm of number of individuals.-Gleason (1922) and Cain (1932) plotted species accumulated versus the area sampled to obtain the now 